PAEDAGOGIA CHRISTIANA

2/26(2010) - ISSN 1505-6872

Andrzej Draguła*

Szczecin

\title{
Dialog wewnętrzny w Kościele
}

Powszechnie wyróżnia się następujące kręgi dialogu, w których bierze udział Kościół: dialog Kościoła z ludzkością i ze „światem”, dialog Kościoła z przedstawicielami innych religii, dialog Kościoła z wyznawcami innych Kościołów chrześcijańskich (tzw. dialog ekumeniczny) oraz dialog wewnątrz wspólnoty Kościoła ${ }^{1}$. O dialogu prowadzonym przez Kościół katolicki ad extra mówi się i pisze względnie dużo. O dialogu ad intra mówi i pisze się niewiele. A jeśli już, to najczęściej w kontekście, że tego dialogu brak² $^{2}$ Dlaczego tak się dzieje?

Według J. Salamona, ,dialog jest wciąż nazbyt często traktowany przez ludzi wierzących tak, jakby był w sferze religii ciałem obcym, przejściową modą importowaną z obszaru polityki, pomagającą być może zachować «polityczną poprawność», ale nie dotykającą tego, co w religii prawdziwie istotne”3. Tymczasem - jak stwierdza J. Wal - „D[ialog] Kościoła ze światem i d[ialog] wewnątrzkościelny nie stanowią taktyki duszpasterskiej, w sytuacji, gdy inne oddziaływania zdają się tracić swoją skuteczność, ale wynika

* Ks. dr Andrzej Draguła pełni obowiązki kierownika Katedry Teologii Pastoralnej, Liturgiki i Homiletyki w Wydziale Teologicznym Uniwersytetu Szczecińskiego.

1 Zob. R. Łukaszyk, Dialog, w: Encyklopedia katolicka, t. 3, Lublin 1995, kol. 1261.

2 „Zarówno w oficjalnych dokumentach Kościoła, jak i w jego zwyczajnym nauczaniu, często można spotkać zachętę do przyjmowania postawy otwartości i gotowości do dialogu opartego na miłości Boga i bliźniego. Jednak doświadczenie kontaktów z przedstawicielami instytucji kościelnych okazuje się niejednokrotnie sprzeczne z ich deklaracjami”. A. Świeżyński, Kilka uwag na temat dialogu w instytucjach kościelnych. Na marginesie Roku Kapłańskiego, [dostęp:] http://www.opoka.org.pl/biblioteka/T/TA/TAP/as_dialog.html (08.01.2010).

3 J. Salamon, Ku religii wolności, w: J. Makowski, J. Salamon (red.), Chrześcijaństwo przed nami, Kraków 2008, s. 37. 
on z natury Kościoła. Kościół posiada dialogalną naturę i dialogową strukturę, które mu nadał Jezus Chrystus"4.

\section{Chrześcijaństwo jako religia dialogiczna}

Ze względu na obecność czy nieobecność dialogu wewnątrz struktury danej religii, J. Salamon wyróżnia dwa modele religii: dialogiczny ${ }^{5}$ i monologiczny. Rozróżnienie to bierze pod uwagę miejsce i rolę urzędowych „pośredników” w relacji między ludźmi a Bogiem. W odniesieniu do chrześcijaństwa

monologiczny model religii ma tę przypadłość - pisze Salamon - że zdaje się zakładać, że przeznaczeniem większości ludzi jest pozostawanie zawsze w fazie dzieciństwa, pod opieką kompetentnych pośredników między nimi a Bogiem, którzy przekażą im właściwe zakazy i nakazy, jakim mają się podporządkować, oraz którzy będą «orędować» za nimi u Boga, jak gdyby nie można było zaufać zapewnieniu Jezusa o pozytywnej odpowiedzi Boga na miłość człowieka ${ }^{6}$.

W tak rozumianym chrześcijaństwie relacje między Bogiem a człowiekiem oraz w obrębie społeczności religijnej nie mają charakteru partnerskiego. Relacje te opierają się na ,jednokierunkowym przekazie z góry, przekazie nakazów i zakazów odzwierciedlających uprzywilejowane usytuowanie poznawcze wybranych jednostek, wyznaczone posiadaną władzą"7. Model ten przypomina relacje, jakie zachodzą między dziećmi a rodzicami: „milcząca większość jest przedmiotem opieki monologującej mniejszości, która sprawuje władzę poniekąd analogiczną do władzy rodzicielskiej, czyli władzy sprawowanej «dla dobra» podopiecznych"».

Według Salamona chrześcijaństwo - w odróżnieniu do starotestamentalnego judaizmu - jest religią dialogiczną. ,Jezus, choć bynajmniej nie obniża roli wspólnoty, zdaje się kłaść duży nacisk na zaproszenie wszyst-

${ }^{4}$ J. Wal, Dialog, w: R. Kamiński (red.), Leksykon teologii pastoralnej, Lublin 2006, s. $178-179$.

${ }^{5} \mathrm{~W}$ literaturze przedmiotu pojawiają się następujące określenia: dialogiczny, dialogowy, dialogalny. Ich zakresy semantyczne są trudne do jednoznacznego określenia i często używane są zamiennie. J. Wal (Dialog, s. 179) mówi na przykład o „dialogalno-dialogowej aktywizacji Kościoła".

${ }^{6}$ J. Salamon, dz. cyt., s. 47.

7 Tamże, s. 46.

8 Tamże. 
kich i każdego z osobna do głębokiej relacji z Bogiem"”. Dialogiczność chrześcijaństwa opiera się - bez negacji roli i, w pewnych przypadkach, konieczności urzędowych pośredników (kapłanów) - na możliwości wejścia w bezpośrednią relację z Bogiem. Mówi o tym także Paweł VI w Encyklice Ecclesiam suam. ,[...] objawienie, to jest nadprzyrodzona więź, którą sam Bóg ustanowił z ludźmi, może być jakby pewnego rodzaju dialogiem, [...] dzieje zbawienia ludzkiego świadczą o tym długotrwałym i różnorodnym dialogu, który Bóg w sposób przedziwny z ludźmi nawiązuje i w rozmaity sposób dalej prowadzi” (ES 70). Według Papieża, ten „zbawczy dialog”10 pomiędzy Bogiem a ludźmi ${ }^{11}$ jest modelem i źródłem wszelkiego dialogu, jaki Kościół powinien prowadzić.

\section{Chrześcijański model dialogu}

Dialog w ramach struktury religijnej różni się zasadniczo od czegoś, co można nazwać procedurami dialogicznymi, które stosowane są w dyplomacji czy biznesie. Taki model dialogu J. Salamon nazywa „negocjacyjnym” i polega on na poszukiwaniu dróg do osiagnięcia konsensusu osób zajmujących odmienne stanowiska. Można go też nazwać procesem ustalania protokołu rozbieżności ${ }^{12}$. Tym, co odróżnia oba modele dialogu (negocjacyjny i eklezjalny), jest relacja do kategorii ,inności”. W dialogu negocjacyjnym „wszelka «inność» i odrębność jest trudnością, którą dobrze byłoby przezwyciężyć i usunąć jako przeszkodę na drodze do konsensusu, stanowiącego rację zaistnienia tego rodzaju dialogu" ${ }^{\prime 13}$. W dialogu, na jakim opiera się

9 Tamże, s. 47.

10 Do określenia ,dialogu zbawczego" Sobór Watykański II używa dwóch terminów: dialogus oraz colloquium salutis. Zob. J. Wal, Dialog, s. 178; tenże, Rola dialogu w życiu Kościoła, w: R. Kamiński (red.), Teologia pastoralna, t. 1, Lublin 2000, s. 193.

11, ,...] ów prawdziwy i niewymowny rodzaj rozmowy, którą z nami zapoczątkował i nawiązał Bóg Ojciec przez Jezusa Chrystusa w Duchu Świętym” (ES 71). Tekst za wydaniem: Jan XXIII, Paweł VI, Jan Paweł II, Encykliki, Warszawa 1981, s. 81-114; por. R. Łukaszyk, dz. cyt., kol. 1260.

12 Zob. J. Salamon, dz. cyt., s. 37, 45.

13 Tamże, s. 45. „Pojęcie dialogu ma bardzo wiele wspólnego z takimi terminami, jak dyskusja, pertraktacje czy negocjacje. Dialog jednak jest czymś więcej niż dyskusja, pertraktacje czy negocjacje. Nie dotyczy on wyłącznie wymiany myśli i komunikacji wzajemnej w obrębie jakiegoś tematu, ale jest realizacją natury człowieka - jego dialogicznej istoty". J. Wal, Rola dialogu, s. 189. „Dialog, który jest czymś innym niż polemiką czy bezpośrednią i jednostronną próbą nawrócenia, zakłada, że obydwie strony oczekują i chcą nauczyć się czegoś od siebie nawzajem”. K. Rahner, H. Vorgrimler, Mały słownik teologiczny, Warszawa 1987, [hasło:] Dialog, kol. 82. 
chrześcijaństwo, „inność” stanowi istotną wartość i łączy się bezpośrednio z wolnością. „Człowiek, którego horyzont samozrozumienia jest wyznaczony pragnieniem i doświadczeniem wolności, będzie także w relacjach z Bogiem i w przestrzeni religijnej społeczności oczekiwał partnerstwa, wolności od nieuzasadnionego przymusu, poszanowania własnej indywidualności i odrębności, możliwości akceptacji lub odrzucenia proponowanych reguł w zgodzie z własną wolą i sumieniem”14. „Wolność podmiotów dialogu kontynuuje J. Salamon - zawiera w sobie także prawo do ich samookreślenia, dialog zakłada prawo do «inności» partnerów dialogu. Bez zgody na «inność» partnera dialogu znów mamy do czynienia z monologiem, nawet jeśli rozpisanym na dwa czy więcej głosów"15.

Fundamentem dialogu religijnego jest miłość, i to tak dalece, że Paweł VI nazywa dialog „nowym imieniem miłości”" ${ }^{16}$.,[...] konieczną jest rzeczą, by nic innego, jak tylko gorąca i szczera miłość skłaniała nas do dialogu" (ES 73) - wzywa Paweł VI. W dialogu miłości ,inność” jest więc - jak to formułuje Salamon - w dwojakim znaczeniu „do zniesienia”. Po pierwsze, w dialogu miłości „inność” wcale nie musi być usunięta, gdyż „racją zaistnienia dialogu miłości jest sama miłość, czyli bezinteresowne obdarowywanie partnera dialogu”. Po wtóre, ,inność” partnerów w dialogu miłości już jest w jakimś sensie „zniesiona”, gdyż „relacja miłości wiąże partnerów dialogu na poziomie bardziej fundamentalnym, niż poziom, na którym zachodzą różnice poglądów" ${ }^{17}$. W tym znaczeniu dialog wewnątrz religii staje się niemalże synonimem miłości bliźniego ${ }^{18}$. Paweł VI dopowie, że „w dialogu [...] prawda łączy się z miłością, a zrozumienie z ukochaniem" (ES 82) ${ }^{19}$.

14 J. Salamon, dz. cyt., s. 42.

15 Tamże, s. 45. „Dialog nie zlikwiduje zupełnie murów pomiędzy ludźmi. Może jednak doprowadzać do tego, żeby ludzie się różnili, ale nie odgradzali się od siebie; żeby różnice między ludźmi różnych wyznań, religii, kultur i narodów, a także różnych nurtów w łonie tego samego katolickiego Kościoła, stawały się dla nich raczej wzbogaceniem niż zagrożeniem. Dzięki dialogowi można też stopniowo rozbierać mury istniejące: nie gwałtownie burzyć, by zaanektować cudze terytorium intelektu i ducha, lecz cegiełka po cegiełce obniżać ich poziom, aby można było sobie podać rękę w geście szacunku do Innego". A. Draguła, Z. Nosowski, Nowa wyobraźnia dialogu, „Więź” 1 (2008), s. 11-12.

${ }^{16}$ Zob. J. Salamon, dz. cyt., s. 37. „Gdy o Nas chodzi, tę najgłębszą dążność miłości, która ku temu zmierza, by przejść w zewnętrzny dar miłości, nazwiemy przyjętą już nazwą dialogu" (ES 64).

17 J. Salamon, dz. cyt., s. 45-46.

${ }_{18}$ Zob. tamże, s. 37.

19 „Należy podkreślić, że każdy d[ialog] nie tylko budzi «pomysłowość miłości», ale sam w sobie stanowi przejaw tej «pomysłowości miłości»”. J. Wal, Dialog, s. 180. „Ażeby jednak dialog właściwie się rozwijał, niezmiernie jest ważne, by miłość i zjednoczenie panowały nawet tam, gdzie zachodzą różnice zdań i żeby wszyscy gorąco pragnęli umocnienia i zachowania 


\section{Communio jako zasada dialogu wewnątrzkościelnego}

Podejmując kwestię dialogu wewnątrz wspólnoty Kościoła, trzeba wziąć pod uwagę problem swoistej natury Kościoła. W sposób naturalny dialog - jak wspomniano wyżej - odwołuje się do równości partnerów. Rodzi się pytanie, na ile dialog jest możliwy w Kościele nie tylko ze względu na dialogiczną naturę Objawienia, ale także ze względu na strukturę Kościoła. Mówiąc inaczej: czy struktura instytucji Kościoła nosi w sobie zdolność do dialogu? „Czy w strukturach kościelnych jest miejsce na autentyczny dia$\log$ ? Czym powinien się on charakteryzować? A może instytucje kościelne ze swej natury nie mają być miejscem dialogu, lecz jedynie hierarchicznego posłuszeństwa?" - pyta A. Świeżyński ${ }^{20}$. Pozytywną odpowiedź na to pytanie umożliwi odwołanie się do kategorii communio jako zasady Kościoła.

Punktem konstrukcyjnym najstarszej eklezjologii jest eucharystyczne zgromadzenie - Kościół jako communio. Stąd pochodzi nie tylko specyficzne dla całej jego struktury przenikanie się jedności i wielości, ale jest także fundament jedności Chrystusa i Kościoła, który uniemożliwia rozdzielenie widzialnego Kościoła od Kościoła Ducha, Kościoła jako organizacji i Kościoła jako misterium: Kościół jest konkretną communio, która poza tym nigdzie nie istnieje ${ }^{21}$.

- pisał Joseph Ratzinger. Obok pojęcia „ludu Bożego” kategoria communio stanowi zasadniczy teologiczny zrąb myśli soborowej (zob. ChL 19). Według J. Ratzingera, ta teologiczna kategoria stanowiła konieczne uzupełnienie kategorii Kościoła rozumianego jako lud Boży. Jak pisze J. Morawa, teologia Kościoła rozumianego wyłącznie jako lud Boży „,w pierwszych latach jego [soboru] zbyt szybkiej i jednostronnej recepcji, okazała się teologicznie niewystarczająca, a do tego bardzo narażona na niekościelne interpretacje"22. Nadano jej bowiem zbyt socjologiczne znaczenie, redukując do kościelnego ekwiwalentu demokracji. Niestety, jak zauważa dalej J. Ratzinger, także i w interpretacji kategorii communio w teologii posoborowej nie ustrzeżono się błędów.

jedności. Działać należy z wolą budowania, a nie burzenia oraz ze szczerą miłością Kościoła i z gorliwym dążeniem do jedności, którą Chrystus podał jako rozpoznawczy znak prawdziwego Kościoła, zatem i prawdziwych wiernych (por. J 17, 21)” (CeP 118).

${ }^{20}$ A. Świeżyński, dz. cyt.

21 J. Ratzinger, Theologische Prinzipienlehre, München 1982, s. 266-267, [cyt. za:] J. Morawa, Eklezjologia «communio eucharistica» Josepha Ratzingera, „Teofil” 1 (2008), s. 103.

${ }^{22}$ Zob. tamże, s. 102. 
W miarę jak communio - pisze J. Ratzinger - stawało się popularnym, chwytliwym hasłem, ulegało równocześnie spłaszczeniu i zafałszowaniu. Tak samo jak w przypadku kategorii ludu Bożego, tak też i tutaj można było obserwować narastający proces horyzontalizacji i pomijania pojęcia Boga. Eklezjologię komunijną zaczęto coraz wyraźniej redukować do tematu relacji między Kościołami lokalnymi a Kościołem powszechnym, a tę z kolei coraz częściej sprowadzano do zagadnienia podziału kompetencji. Znowu zjawił się też - jakże by nie! - wątek egalitarystyczny, zgodnie z którym w communio mogą istnieć tylko całkowicie równi sobie ${ }^{23}$.

J. Ratzinger wskazuje więc na poprawne rozumienie tej kategorii. Punktem wyjścia jest dla niego biblijny obraz powołania Piotra zanotowany przez św. Łukasza (5, 1-11). Na określenie relacji pomiędzy Jakubem i Janem a Piotrem ewangelista używa określenia koinonoi, co można przetłumaczyć jako 'współtowarzysze'. Termin ten używany był na określenie współdziałania przez wspólną własność, wspólną pracę i wspólne wartości w prowadzeniu zakładu wytwórczego, w tym przypadku - małego przedsiębiorstwa Piotra. W ten sposób - jak to formułuje J. Ratzinger - Ewangelia zaczyna opowiadać o przemianie prywatnej kooperatywy Piotra w komunię Kościoła ${ }^{24}$. Greckie pojęcie koinonia znajduje swoją kontynuację w łacińskim communio $^{25}$. Zarówno grecka, i jak i łacińska etymologia pojęcia communio, rozumianego jako wspólnota, wskazuje więc nie na aspekt współrówności, egalitaryzmu czy po świecku rozumianej demokracji, ale na aspekt współpracy, współodpowiedzialności, współpodmiotowości i współzależności pomiędzy członkami i częściami Kościoła. Kościół rozumiany jako communio nie może zostać sprowadzony ani do widzialnej struktury instytucjonalnej, ani jedynie do rzeczywistości nadprzyrodzonej, nie jest bowiem ani jedynie widzialny, ani jedynie niewidzialny ${ }^{26}$. Kategoria communio pozwala na wyrażenie szczególnego związku pomiędzy poszczególnymi członkami Kościoła rozumianego jako jedno ciało i żywa struktura. Jednocześnie pozwala

${ }^{23}$ J. Ratzinger, Kościót. Pielgrzymujaca wspólnota wiary, Kraków 2005, s. 116.

${ }^{24}$ Tamże, s. 63; tenże, Chrystus i Jego Kościót, Kraków 2005, s. 109.

25 „Tam [...] gdzie decydującymi czynnikami są wola i osobiste pragnienia, tam rozdarcie dokonuje się już w punkcie wyjścia, ze względu na wielość i przeciwstawność upodobań. W wyniku podobnych wyborów ideologicznych powstają kluby, kręgi przyjaciół, partie, ale nigdy Kościół będący poza wszelkimi podziałami i jednoczący ludzi w pokoju z Bogiem. Zasadą, w oparciu o którą powstaje klub, jest osobiste upodobanie, ale zasadą, na której wznosi się Kościól, jest posłuszeństwo wezwaniu Pana [...]”. J. Ratzinger, Partia Chrystusa czy Kościót Chrystusa?, „Znak” 10 (1992), s. 147.

${ }^{26}$ Zob. A. Draguła, Kościół. Wyrzekając się sukcesu, w: J. Makowski, J. Salamon (red.), dz. cyt., s. $73-84$. 
na uniknięcie dwóch skrajności - postrzegania Kościoła jedynie jako struktury hierarchicznej, a więc w konsekwencji autorytarnej i niedialogicznej, oraz - z drugiej strony - postrzegania Kościoła jako grupy egalitarystycznej, w której wszyscy pozostają wobec siebie w relacji równości ${ }^{27}$.

\section{Uwarunkowania dialogu wewnątrzkościelnego}

Summą kościelnego nauczania o dialogu jest Encyklika Pawła VI Ecclesiam suam o drogach, którymi Kościół katolicki powinien kroczyć w dobie obecnej przy pełnieniu swojej misji. Kwestii dialogu wewnątrzkościelnego autor poświęca zaskakująco niewiele miejsca, bo tylko jeden punkt (ES 113). Przytoczmy go w całości:

$\mathrm{Na}$ koniec nasz dialog kieruje się ku synom, będącym w domu Bożym, to jest w jednym, świętem i apostolskim Kościele, którego Kościół Rzymski jest «matką i głową». Jakżebyśmy chcieli, ażeby taką rodzinną rozmowę cechowała pełnia wiary, miłości oraz dobrych uczynków. Jak bardzo pragniemy, żeby była częsta i zażyła. Żeby była na oścież otwarta na wszystkie prawdy, wszystkie cnoty i wszystkie duchowe dobra, zawarte w dziedzictwie chrześcijańskiej nauki. Żeby była szczera, a zarazem znajdowała podnietę w rzetelnej pobożności. Ogromnie skora do wysłuchiwania przeróżnych głosów współczesnych nam ludzi. I wreszcie tak przydatna do urobienia katolików na ludzi na wskroś dobrych, rozważnych, wolnych, zrównoważonych i mężnych (ES 113).

Jak widać, w rozumieniu Pawła VI dialog wewnątrz wspólnoty Kościoła powinien być ,rodzinną rozmową”, pełną ,wiary, miłości oraz dobrych uczynków". Tak rozumiany dialog jest wyrazem wzajemnej współodpowiedzialności wszystkich członków Kościoła za siebie oraz za samą instytucję Kościoła $^{28}$.

Według J. Wala, podstawowa równość podmiotów dialogu wewnątrzkościelnego została zachowana zarówno na płaszczyźnie naturalnej, jak i nadprzyrodzonej. Na płaszczyźnie naturalnej o równości decydują: rozumność i wolność wszystkich ludzi oraz wspólne doświadczenie ludzkiego losu. Na płaszczyźnie nadprzyrodzonej źródłem równości są: stworzenie na obraz i podobieństwo Boże, odkupienie wszystkich ludzi przez Chrystusa i powołanie do szczęśliwości wiecznej ${ }^{29}$. Sakramentalnym źródłem dialo-

27 Zob. J. Morawa, dz. cyt., s. 105.

28 Zob. A. Draguła, Kościót, którego szukam, „W drodze” 10 (2008), s. 45-48.

${ }^{29}$ Zob. J. Wal, Rola dialogu, s. 195-196. 
gu wewnątrzkościelnego jest jednakowa dla wszystkich członków Kościoła godność dziecka Bożego otrzymana na chrzcie świętym, a tym samym równość w powszechnym kapłaństwie wynikającym z sakramentów inicjacji chrześcijańskiej. W tym znaczeniu dialog wewnątrzkościelny jest najpierw dialogiem podmiotów równych sobie w godności, zbawczym statusie i pierwotnej kompetencji sakramentalnej. Trzeba podkreślić, iż pierwotna kompetencja sakramentalna wszystkich członków Kościoła jest taka sama, dopiero wewnątrz niej następuje zróżnicowanie na stany, urzędy, posługi i charyzmaty, które służą temu samemu celowi, jakim jest budowanie Kościoła. Jak przypomina Sobór Watykański II, cały lud Boży, nie tylko hierarchia, ale także świeccy, zostali wyposażeni przez „zmysł wiary i łaskę słowa” (sensus fidei et gratia verbi, zob. KK 12, 35), co uzdalnia ich do prowadzenia wzajemnego dialogu ${ }^{30}$. Jego ostatecznym celem jest poszukiwanie prawdy, które dokonuje się przez ,wymianę myśli i dialog, przez co jedni drugim przedkładają prawdę, którą znaleźli albo sądzą że znaleźli, by pomagać sobie nawzajem w jej zgłębieniu" (DWR 3). W ten sposób zachowane pozostają relacje typowe dla wspólnoty, jaką jest communio Ecclesiae.

Oczywiście, warunkiem tak prowadzonego dialogu jest uznanie partnerskiej roli wszystkich podmiotów prowadzących dialog oraz przyjęcie teologicznego (nie tylko teoriopoznawczego założenia), że poznanie i zgłębienie prawdy jest owocem wzajemnych poszukiwań. Uznanie partnerskiej roli podmiotów dialogu wewnątrzkościelnego nie unieważnia jednak istniejącego zróżnicowania ról, wynikających z pełnionych w Kościele funkcji i urzędów, a także relacji posłuszeństwa ${ }^{31}$. Mając to na względzie, Paweł VI stwierdza: „Jeżeli więc sobie życzyć, by wewnętrzną więź Kościoła przepajało poczucie należne rozmawiającym z sobą członkom tej samej wspólnoty, której podstawą jest miłość, to w niczym jednak nie można uchybiać cnocie posłuszeństwa [...]" (ES 114). Jak zauważa J. Wal, dialog wewnętrzny jest w pewnym sensie łatwiejszy niż dialog zewnętrzny, gdyż „,istnieje podstawowa baza prawd i wartości wspólnie przyjmowanych", jednocześnie jednak istotnym utrudnieniem dialogu jest „zróżnicowanie pozycji partnerów”, które w sposób niejako naturalny hierarchizuje biorących udział w dialogu ${ }^{32}$.

${ }^{30}$ Zob. A. Szafrański, Dialog wewnatrzkościelny, w: Encyklopedia katolicka, t. 3, kol. 1262.

${ }^{31}$ Z punktu widzenia językoznawczego można tutaj mówić o dialogu, który dokonuje się pomiędzy partnerami o rangach równorzędnych (np. między biskupami, między kapłanami, między wiernymi) oraz o rangach nierównorzędnych: podrzędność, nadrzędność (np. między biskupem a kapłanami, kapłanem a wiernymi). Zob. S. Grabias, Język w zachowaniach społecznych, Lublin 1994, s. 235-236.

32 J. Wal, Dialog, s. 178. 
Dodajmy, że dialog zewnętrzny dokonuje się najczęściej pomiędzy partnerami o podobnym statusie i zbliżonej randze.

\section{Struktury dialogowe w Kościele}

„Naturalny rytm i pełnienie zadań w Kościele wymagają, by pomiędzy władzami kościelnymi na wszystkich poziomach, instytucjami katolickimi a wiernymi, miał miejsce ciagły przepływ wiadomości i opinii w obu kierunkach oraz by wszystko rozchodziło się na cały świat" - czytamy w Communio et progressio (CeP 120). W związku z tym, wraz z rozwojem samoświadomości Kościoła w odniesieniu do własnej dialogalnej natury, co dokonało się przede wszystkim na Soborze Watykańskim II, powołano w Kościele różnego rodzaju struktury dialogalne, które funkcjonują na różnych płaszczyznach Kościoła: od poziomu Kościoła powszechnego aż do płaszczyzny parafialnej. Do dialogu wewnątrz Kościoła powszechnego służą przede wszystkim: sobór powszechny, reaktywowany po soborze synod biskupów oraz papieskie rady działające bezpośrednio przy Stolicy Apostolskiej. Forum dialogu regionalnego i krajowego stanowią regionalne i krajowe konferencje biskupów oraz synod plenarny. W Kościele partykularnym do prowadzenia dialogu powołane są takie struktury, jak: rada konsultorów, rada kapłańska, diecezjalna rada duszpasterska, zaś na płaszczyźnie parafialnej powinny działać parafialne rady duszpasterskie (zob. KK 12) ) $^{33}$. Do struktur tych należy jeszcze doliczyć Urząd Nauczycielski Kościoła, a także uczelnie katolickie, dialog teologiczny oraz dyskurs religijny prowadzony w mediach ${ }^{34}$.

Realizacja dialogu wewnątrzkościelnego przez ludzi świeckich ujawnia się strukturalnie poprzez udział $\mathrm{w}$ instytucjach doradczych, istniejących na wielu płaszczyznach Kościoła. Mówiąc o udziale świeckich w diecezjalnych radach duszpasterskich (zob. KPK 511-514, DB 27), Jan Paweł II pisał, że „w rzeczywistości chodzi tu o zasadniczą formę współpracy i dialogu, a także rozpoznania na szczeblu diecezjalnym. Udział świeckich w tych radach pozwoli rozszerzyć zakres konsultacji, a zasady współpracy, mającej w pewnych przypadkach charakter decyzjonalny, będzie stosowana szerzej i odważniej" (ChL 25, por. KPK 511, 512). Udział świeckich przewidziany jest także w synodach diecezjalnych oraz partykularnych: prowincjonalnych i plenarnych (por. ChL 25, KPK 443, par. 4). Zadaniem Konferencji Episkopatu jest wypracowanie takich metod, aby jak najlepiej ujawniała się funkcja doradcza laikatu, a przez to „uwidoczniła się wyraźniej kościelna komunia

${ }_{33}$ Zob. J. Wal, Dialog, s. 179; A. Szafrański, dz. cyt., s. kol. 1263-1270.

${ }^{34}$ Zob. tamże. 
wszystkich" (ChL25). Zalecenia te należy także odnieść do instytucji parafialnej rady duszpasterskiej postulowanej przez Kodeks Prawa Kanonicznego (zob. KPK 536) oraz soborowy Dekret o apostolstwie świeckich (zob. DA 26) ${ }^{35}$. Oprócz celów ściśle praktycznych, jakimi są wypracowywanie nowych, skutecznych metod duszpasterskich oraz aktywizacja laikatu, rady duszpasterskie mają za zadanie „wytwarzanie wśród wiernych świadomości wspólnoty Kościoła"36.

\section{Przedmiot i formy dialogu}

Według A. Szafrańskiego, ,przedmiotem d[ialogu] wewnątrzkościelnego są prawdy wiary, zasady moralności i liturgia oraz życie chrześc[ijańskie] w społeczności Kościoła i świata" ${ }^{37}$. Ze względu na szczegółowy przedmiot dialogu, może on służyć rozmaitym celom. Jeśli chodzi o dialog za pomocą struktur kościelnych, to o ile na poziomie parafialnym i diecezjalnym (Kościoła partykularnego) służy on przede wszystkim celom duszpasterskim, o tyle dialog prowadzony na poziomie Kościoła powszechnego koncentruje się bardziej na kwestiach doktrynalnych. Przykładem takiego dialogu może być - choć wykraczające poza Kościół katolicki - zaproszenie wyrażone wprost przez papieża Jana Pawła II do teologów i zwierzchników Kościołów do podjęcia dialogu teologicznego na temat sposobu sprawowania posługi prymatu Piotra ${ }^{38}$.

Dialog teologiczny podlega istotnemu ograniczeniu, jakim jest pozostawanie wewnattrz ortodoksyjnej nauki Magisterium Ecclesiae. Z jednej strony ,[...] prawdy wiary sięgają samej istoty Kościoła i [...] jako takie nie mogą być przedmiotem swobodnej interpretacji poszczególnych osób", z drugiej jednak ,tak długo [...] jak katolicy pozostają wierni Magisterium, mogą i powinni w sposób wolny poszukiwać i zgłębiać prawdy objawione oraz wyrażać je w sposób bardziej odpowiadający zmianom społecznym" (CeP 117). Jednocześnie jednak trzeba jednoznacznie odróżnić badania na-

${ }^{35}$ Zob. R. Kamiński, Parafia miejscem realizacja duszpasterstwa, w: R. Kamiński (red.), Teologia pastoralna, t. 2, Lublin 2002, s. 49-54.

36 Tamże, s. 53.

${ }^{37}$ A. Szafrański, dz. cyt., kol. 1263.

38 „Czy zatem realna, choć niedoskonała komunia, istniejąca między nami, nie mogłaby nakłonić kościelnych zwierzchników i ich teologów do nawiązania ze mną braterskiego i cierpliwego dialogu na ten temat, w którym moglibyśmy wzajemnie wysłuchać swoich racji, wystrzegając się jałowych polemik i mając na uwadze jedynie wolę Chrystusa wobec Jego Kościoła, przejęci do głębi Jego wołaniem: «aby i oni stanowili w Nas jedno, aby świat uwierzył, żeś Ty Mnie posłał» (J 17, 21)?”(UuS 96). 
ukowe (teologiczne), które są forma prowadzenia dialogu wewnątrzkościelnego, od nauczania wiernych. W przypadku działalności badawczej „osoby naprawdę kompetentne winny cieszyć się wolnością niezbędną w ich działalności, aby mogli przekazywać także innym, za pomocą artykułów i książek, wyniki swoich badań”. W nauczaniu wiernych „winno się przedstawiać jedynie autentyczną naukę Magisterium Kościoła uznaną przezeń za pewną" (CeP 118). Normy dotyczące dialogu teologicznego w Kościele zostały opublikowane w Instrukcji Donum varitatis o powołaniu teologa w Kościele (1990). Dla interesującego nas problemu dwie uwagi z tego dokumentu wydają się istotne. Pierwsza to wskazanie, iż właściwa badaniom teologicznym wolność domaga się uzupełnienia poprzez „braterski dialog” z Urzędem Nauczycielskim Kościoła. Druga, iż dialog ten musi kierować się dwiema zasadami: „tam, gdzie chodzi o komunię wiary, obowiązuje zasada unitas veritatis; tam zaś, gdzie istnieją różnice, które tej komunii nie naruszają, należy trzymać się zasady unitas caritatis" (26).

Celem wewnętrznego dialogu duszpasterskiego jest przede wszystkim poznanie potrzeb wiernych, a także opinii na temat nowych form pracy duszpasterskiej. Systematyczne prowadzenie takiego dialogu umożliwia właściwe odczytanie aktualnych problemów społeczności wierzących oraz zapewnia znalezienie form bardziej odpowiadających mentalności współczesnych ludzi. Partner dialogu jest często w posiadaniu tego rodzaju doświadczenia, które w zwyczajnej sytuacji pozostaje niedostępne ${ }^{39}$. Jest tak w przypadku problemów dotyczących etyki małżeńskiej, które w normalnej sytuacji pozostają dla kapłana zagadnieniem teoretycznym. Mając świadomość, że „Kościół postępuje naprzód wraz z historią ludzkości”, „w swych diecezjach winien on przystosować się do zmiennych warunków czasu i miejsca czy to, by odpowiednio przedstawiać prawdy wiary, stosownie do różnych sytuacji historycznych, różnic cywilizacyjnych i kulturalnych czy też, aby przystosować praktykę duszpasterską do przemian czasu i do konkretnych okoliczności" (CeP 117).

Szczególną formą dialogu duszpasterskiego jest postulowany coraz częściej dialog kaznodziejski, polegający na włączaniu grupy świeckich w proces przygotowania oraz ocenę homilii (kazania). Jego celem jest jak najlepsze odczytanie kerygmatu Ewangelii w kontekście problemów współczesnego człowieka, tak aby zbawczy dialog był coraz lepiej aktualizowany i odbierany przez słuchacza jako żywy i bezpośrednio dotykający jego życia. „Odmienny sposób przyjmowania tekstu [...] ma swe podłoże w odmienności naszych uprzednich doświadczeń, pragnień, okaleczeń, które są żywe

39 Zob. K. Rahner, H. Vorgrimler, dz. cyt., kol. 83. 
w każdym z uczestników" - pisze Rolf Zerfass ${ }^{40}$. Dialog kaznodziejski pozwala na rzeczywiste rozpoznanie w wiernych partnerów w dialogu człowieka z Bogiem, objawiającym się w słowie.

\section{Uznana różnorodność}

Dialog wewnątrzkościelny dokonuje się nie tylko w ramach samej struktury Kościoła, ale także w przestrzeni dyskursu publicznego. Jak czytamy w Instrukcji Communio et progressio, „Kościół jest żywym organizmem i potrzebuje opinii publicznej, która rodzi się z dialogu jego członków, będącym warunkiem rozwoju myśli i działalności Kościoła" (CeP 115). Dokument stwierdza dalej, że ,jest rzeczą niezbędna, by wierni byli w pełni świadomi posiadania autentycznej wolności wyrażania własnych poglądów, co znajduje swoją podstawę $\mathrm{w}$ miłości i w tym, co określamy «zmysłem wiary»”. Dlatego „władze, których to dotyczy, niech troszczą się i zapewniają w Kościele normalną wymianę uprawnionych opinii, ogłaszając w tym celu właściwe normy”. Dokument postrzega dialog nie jako „zło konieczne”, które niejako zostało wymuszone przez społeczeństwo liberalne, ale jako istotną wartość, która może służyć dobru Kościoła: „ta wolność słowa w Kościele nie tylko nie szkodzi jego trwałości i jedności, ale dynamizując opinię publiczną, może sprzyjać i służyć zgodzie i harmonii dusz" (CeP 117).

Istotnym warunkiem prowadzenia dialogu jest uznanie prawa do informacji oraz zasada jawności informacji rozpowszechnianych wewnątrz Kościoła. „[...] uznaje się - czytamy we wspomnianej Instrukcji - że poszczególni wierni, aby mogli brać czynny udział w życiu Kościoła, posiadają możliwość i prawo do informacji o wszystkich wydarzeniach" (CeP 119). Dokument przestrzega przed chęcią utajniania informacji dotyczących działania Kościoła, gdyż „,wówczas łatwo mogą powstać pogłoski, które krążąc wśród ludzi raczej szkodzą niż pomagają głoszeniu prawdy" (CeP 121). Dlatego uznawanie informacji za tajemnicę powinno zostać ograniczone do przypadków niezbędnie koniecznych, wymaganych ze względu na dobre imię innych osób, prawa jednostki czy grupy (por. CeP 121). Na marginesie należy dodać, iż w Kościele tendencja do utajniania jest wciąż o wiele silniejsza niż tendencja do ujawniania.

Szczególnie ważnym narzędziem kształtowania w Kościele opinii publicznej są we współczesnym świecie środki społecznej komunikacji (mass media). Podejmując jednak dialog za pomocą mediów, należy wziąć pod uwagę naturę środków przekazu, która istotnie wpływa na kształt prowadzo-

${ }^{40}$ R. Zerfass, Od perykopy do homilii, t. 2, Kraków 1995, s. 82. 
nego dialogu. Po pierwsze - traktując informacje jak towar - media dążą do jak najszybszego ich upowszechnienia. W związku z tym, iż „nowe opinie teologów bywają rozpowszechniane przedwcześnie i w niewłaściwy sposób”, należy je „przyjmować krytycznie i nie traktować ich za autentyczną doktrynę Kościoła". Po drugie, poglądy rozpowszechniane za pomocą mediów „często docierają [...] poważnie zniekształcone wskutek nie naukowego, lecz popularnego przedstawienia właściwego środkom przekazu" (CeP 118).

Nieodłącznym elementem dialogu, a jednocześnie jego koniecznym warunkiem jest więc uznana różnorodność w Kościele. Dialog bowiem zakłada inność oraz wielość (pluralizm). Jak podkreśla Hans Urs von Balthazar, w odniesieniu do tajemnicy Objawienia (a w konsekwencji także w odniesieniu do Kościoła) należy używać pojęcia wielość (Pluralität) a nie pluralizm (Pluralismus). Nie chodzi tutaj bowiem o taką różnorodność, z jaką mamy do czynienia w socjologii czy filozofii, ale o wielość w jedności, albowiem dawcą wielości i dawca jedności jest ten sam Duch ${ }^{41}$. „Jeden i ten sam Duch stanowi zawsze dynamiczną zasadę jedności i różnorodności Kościoła i w Kościele" - przypomina Jan Paweł II (ChL 20). Sobór Watykański uznaje różnorodność konkretnych rozwiązań duszpasterskich oraz stanowisk i opinii ludzi świeckich, ale przestrzega przed nieuzasadnionym powoływaniem się na autorytet Kościoła, aby tym samym legitymizować którąś z opcji jako stanowisko urzędowe, to znaczy jedynie poprawne i właściwe. W Konstytucji duszpasterskiej o Kościele w świecie współczesnym czytamy, że „chrześcijańska wizja rzeczywistości skłoni ich [świeckich] w konkretnych warunkach do określonych rozwiązań. Inni jednak wierni powodowani nie mniejszą uczciwością jak to się często i całkiem słusznie zdarza, będą mieć w tej sprawie inne zdanie". Poprzez łączenie konkretnego rozwiązania z ,przesłaniem ewangelicznym”, nawet przez wiele osób, nie wolno jednak „zawłaszczać autorytetu Kościoła wyłącznie na rzecz własnego rozwiązania”. W takiej sytuacji należy „w szczerej rozmowie oświecać siebie nawzajem, zachowując wzajemną miłość i troszcząc się przede wszystkim o dobro wspólne" (KDK 43) ${ }^{42}$. W ten sposób różne opcje i stanowiska będą postrzegane jako zróżnicowane formy tego samego posłannictwa.

${ }^{41}$ Zob. H. U.von Balthasar, Jedność i wielość teologii Nowego Testamentu, „Communio” (wersja polska) 2 (1983), s. 37.

${ }^{42}$ Zob. A. Draguła, Czy istnieje pluralizm ewangeliczny? Dylematy kaznodziejskie, w: A. Offmański (red.), Polska katecheza wobec pluralizmu jednoczqcej się Europy, Szczecin 2004, s. 115-130. 


\section{Zakończenie}

Dialog, opinia publiczna i wolność słowa - pojęcia te nie pochodzą z klasycznego słownika teologicznego. Można by powiedzieć, że zostały zapożyczone z terminologii świeckiej i bezpośrednio kojarzą się ze społecznością pluralistyczną i liberalną. Najistotniejsze pytanie dotyczące dialogu wewnątrzkościelnego brzmi: czy dialog i postawa dialogiczna (oraz jej konsekwencje) wynikają z samej natury Kościoła, czy też są obcym zapożyczeniem, wynikającym z konieczności dopasowania się do współczesnej świeckiej społeczności. Linia demarkacyjna między zwolennikami a przeciwnikami dialogu w Kościele będzie tożsama z udzieleniem pozytywnej bądź negatywnej odpowiedzi na postawione pytanie. Przeciwnicy dialogu w Kościele stawiają najczęściej tezę, iż prowadzi on, czy nawet zakłada, utratę własnej tożsamości ${ }^{43}$. Zwolennicy będą uznawać, iż dialog jest najlepszym wyrazem tożsamości, gdyż ,spotkanie z innym pozwala lepiej zrozumieć samego siebie" 44 .

\section{Der innere Dialog in der Kirche (Zusammenfassung)}

Der Autor des Artikels stellt die These, dass der innere Dialog in der Kirche aus der dialogischen Natur der Offenbarung sowie aus der dialogischen Struktur der Kirche resultiert. Nach J. Salamon ist das Christentum eine dialogische Religion, eine solche also, in welcher der Mensch durch Vermittlung der Gemeinschaft der Kirche, sowie auch persönlich zu dem Dialog (Gespräch) mit dem Gott (Dialog des Heils, colloquium salutis) eingeladen ist.

Der Dialog in der Kirche wird nicht als Negotiationen oder Verhandlungen verstanden, sondern als der praktische Ausdruck der Nächstenliebe, welche das Anderssein zu akzeptieren vermag. Die wichtigsten Formen des Dialogs in der Kirche sind der doktrinelle (theologische) Dialog sowie der pastorale Dialog. Die

${ }^{43}$ „Czas dialogu, poznawania się wzajemnego czy wzajemnej akceptacji poglądów, wydaje się dobiegać końca. Zaczyna się okres ostrego konfliktu ideowego. I dotyczy to nie tylko Polski, z naszymi sporami o aborcję, eutanazję czy handel w niedziele. Kościół, a może lepiej powiedzieć Kościoły i wspólnoty chrześcijańskie, po okresie «inkluzyjności», stawiania na dialog, otwartości i pluralizmu dość gwałtownie wracają do własnych tożsamości. Świadectwem tego jest w Kościele katolickim przywrócenie pełnych praw liturgii trydenckiej czy przypominanie w kolejnych dokumentach tradycyjnego stanowiska w kwestii tożsamości eklezjalnej katolicyzmu”. T. P. Terlikowski, Koniec katolicyzmu otwartego?, „Rzeczpospolita”, 04.08.2007r.

${ }^{44}$ A. Draguła, Z. Nosowski, dz. cyt., s. 7. 
Kirche besitzt dialogische Strukturen auf allen Ebenen, d.h. auf der allgemeinen sowie auf der lokalen und der Ebene der Pfarrei. Die Grundlage des Dialogs bildet die Anerkennung aller Glieder der Kirche (Laien und Klerus) als Partner des Dialogs unter Berücksichtigung des Unterschiedes der Rollen, Funktionen und Ämter. Der Dialog setzt die Pluralität in der Kirche voraus, die nicht soziologisch verstanden wird (Pluralismus), sondern als Einheit in der Mannigfaltigkeit. Nur in einer solchen Perspektive sind in der Kirche öffentliche Meinung sowie Meinungsfreiheit möglich. $\mathrm{Zu}$ den Haupthindernissen im Dialog gehören: der Anspruch einzelner Gruppen und Optionen auf ausschließliche Identifikation mit der Kirche, sowie die Bevorzugung der hierarchischen Struktur der Kirche vor ihrer gemeinschaftlichen Natur (communio). 
